\title{
Potential Ecological and Health Risk Assessment of Dumpsite from Ibadan, Southwestern Nigeria
}

\author{
R. A. Obasi $†$ and H. Y. Maduekwe \\ Department of Geology, Ekiti State University, Ado Ekiti, Ekiti State, Nigeria \\ †Corresponding author: R.A Obasi; romanus.obasi@eksu.edu.ng
}

Nat. Env. \& Poll. Tech.

Website: www.neptjournal.com

Received: 05-04-2020

Revised: 19-06-2020

Accepted: 25-06-2020

Key Words:

Dumpsites

Ecological risks

Hazard index

Cancer risks

\begin{abstract}
Dumpsites have elevated the contamination and pollution of soils by heavy metals, hence the need to study the potential ecological and health risks impact on the soil and humans. Ten soil samples collected from the soil around the dumpsites at Awotan Ibadan were analysed using the inductively coupled plasma-mass spectrometry (ICP-MS) analytical technique. The data were interpreted using contamination indices such as contamination and enrichment factors, geo-accumulation index and pollution index to determine the ecological and health risks posed by the heavy metals. The results of the spatial distribution of heavy metals across the sampling sites showed the following ranges: $\mathrm{Cu}$ (43.71-469.64) with a mean of $113.74 \mathrm{mg} / \mathrm{kg}, \mathrm{Zn}(53.50-615.60)$ with a mean of $130.52 \mathrm{mg} / \mathrm{kg}$, $\mathrm{Rb}$ (83.14-225.35) with a mean value of $145.37 \mathrm{~g} / \mathrm{kg}$ and $\mathrm{Pb}(28.38-209.15)$ with a mean of 68.01 $\mathrm{mg} / \mathrm{kg}$ in descending order: $\mathrm{Zn}>\mathrm{Cu}>\mathrm{Rb}>\mathrm{Pb}>\mathrm{V}$. The enrichment factors indicated very high enrichment of $\mathrm{Cu}$ (25.07), significant enrichment of $\mathrm{Pb}$ (18.78) and moderate enrichment of $\mathrm{Zn}$ (15.14) and minor enrichments of $\mathrm{Co}, \mathrm{Ni}, \mathrm{Rb}$ and $\mathrm{Cs}$. The results of the contamination factor showed that $\mathrm{Sc}, \mathrm{Co}, \mathrm{Zn}, \mathrm{Rb}$, $\mathrm{Cs}$ have moderate contamination while $\mathrm{Cu}$ and $\mathrm{Pb}$ indicated high contamination. The results of geoaccumulation (Igeo) indicated that $\mathrm{Cu}$ and $\mathrm{Pb}$ are positive in contrast to the other metals suggesting some anthropogenic influences of the duo heavy metals in the study area. $\mathrm{Cu}$ and $\mathrm{Zn}$ indicated low ecological risks however, $\mathrm{Cu}$ and $\mathrm{Pb}$ showed considerable risks (Er 80-160) and moderate risk (Er 40-80) respectively in sample site number one. The results of the modified ecological risk index (MRI) revealed that about $62.53 \%$ of this sample site number one showed a considerable ecological risk of the heavy metal $\mathrm{Cu}$ and $47.61 \%$ of the moderate ecological risk of $\mathrm{Pb}$. The health-risk study indicated that hazard quotient $\mathrm{HQ}_{\mathrm{ing}}, \mathrm{HQ}_{\text {derm }}$ and hazard index $(\mathrm{HI})$ values were below the acceptable limit of $1 \times 10^{-6}$ and $1 \times 10^{-4}$ and therefore showed no obvious non-carcinogenic risk and negligible cancer risk from the soils and environment.
\end{abstract}

\section{INTRODUCTION}

Nigeria like any other developing country of the world increases in population on daily basis, and this increases infrastructure and waste discharges. Cities such as Ibadan the second largest after Lagos in South-West Nigeria produces large quantities of solid wastes from domestic, industrial and institutional wastes. These wastes exist in semi-solid or solid form except for industrial hazardous wastes (USEPA 2012). In most cities in Nigeria, the wastes are not sorted out unlike in developed countries like the UK where there are separate containers for semi and solid wastes collections and these are disposed of according to the environmental protection guidelines of the country in question. In Nigeria, the wastes are dumped in open places called dumpsites or landfills. The wastes decompose or broken down by microorganisms producing leachates which filtrate into the soils and reposited. The plants absorb the leachates through their roots and some of the leached constituents enter the water regime to make it unusable for a drink. Some major problems faced by the cities concerning wastes are improper disposal methods which have serious negative effects on human beings, animals and the environment. The environment represented by the ecosystem via the soil becomes the repository of the heavy metals. Heavy metals are one of the important pollutants in the environment through natural or anthropogenic activities of man. Living organisms require a trace amount of heavy metals but excess of it could be deleterious to them.

Exposures of heavy metals can lead to accumulation in human body parts such as the brain, liver, bones, and kidneys resulting in serious health hazards (Kamunda et al. 2016). Health risk assessment of heavy metals is usually performed to estimate the total exposure to heavy metals among the residents in a particular area. Risk assessment of contaminants in humans is based on the fact that the leachates from the heavy metals can contain chemicals that may either be carcinogenic or non-carcinogenic (Dorne et al. 2011). In the same way, the accumulation of these metals in the body 
system could result in serious life-threatening illnesses and in some cases death.

However, the accumulation of these metals in the body of mammals over time can cause serious illness (Aderinola et al. 2009). Another way heavy metals could be deposited in the body is through agricultural activities. Crop cultivation, happening around dump site could be contaminated since some of the heavy metals gets leached deep into the soil and crops get their nutrient from the soil. When such food is consumed by man, he unintentionally ingests these metals along with the food, poisoning his system and if not checked, over time could result in life-threatening issues. Environmental contamination by heavy metals has become a worldwide problem in recent years since heavy metals unlike some other pollutants are not biodegradable (Bazrafshan et al. 2015). Soil pollution by heavy metals has serious health implication especially with regards to crops/vegetables grown on such soils (Steffan et al. 2017, and Nwaogu et al. 2014). Most of these heavy metals are necessary for both plants and animal growths at uncontaminated levels.

Long-term effect of heavy metal exposure to human and higher animals includes mental lapse, kidney failure, and central nervous system disorder (Nwaogu et al. 2014). Exposure to lead $(\mathrm{Pb})$ may cause anaemia, nephropathy, gastrointestinal colic, and central nervous system symptoms (Hu et al. 2017). As a result of increasing anthropogenic activities, heavy metals pollution of soil, water, and atmosphere represents growing environmental problems affecting food quality and human health. Heavy metals may enter the food chain as a result of their uptake by edible plants (Shaapera et al. 2013). Ibadan, like any other city in South-Western Nigeria, faces problems of environmental sanitation such as improper disposal of refuse near residential areas, along the roads and streets, poor refuse collection and handling. There are four major dumpsites in Ibadan namely; Lapite, Awotan, Ajakanga and Aba Eku and unfortunately farmers use them as fertilizers. This, however, leads to the accumulation of heavy metals in plants grown around the dumpsite soils or on soils fertilized with dumpsite manure thus posing potential health risks.

Dumpsite wastes are commonly burnt and ashes produced are richer in metal contents. These ashes are either dissolved in rainwater and leached into the soil contaminating the underground water, or washed away by runoff into streams and rivers, thereby contaminating the environment. It is based on these facts that this study is aimed at determining the total lethal concentrations or otherwise of Scandium (Sc), Lead $(\mathrm{Pb})$, Copper $(\mathrm{Cu})$, Nickel (Ni), Vanadium (V), Rubidium (Rb), Molybdenum ( Mo), Cobalt (Co), Cesium ( Sc) and Zinc ( Zn) in dumpsite soils in Ibadan area, Nigeria. The topography of the sites is gently undulating with isolated inselbergs at the Awotan area. Migmatite gneisis and quartz schist ridges dominate the terrain. The annual average rainfall in the area is $1300 \mathrm{~mm}$ (Ileoje 1987). The vegetation is the tropical rain forest with thick undergrowth. Dendritic drainage pattern characterizes the area with unmodified stream channels flowing in the southward and east-west directions. The Awotan dumpsite is drained by River Alapata

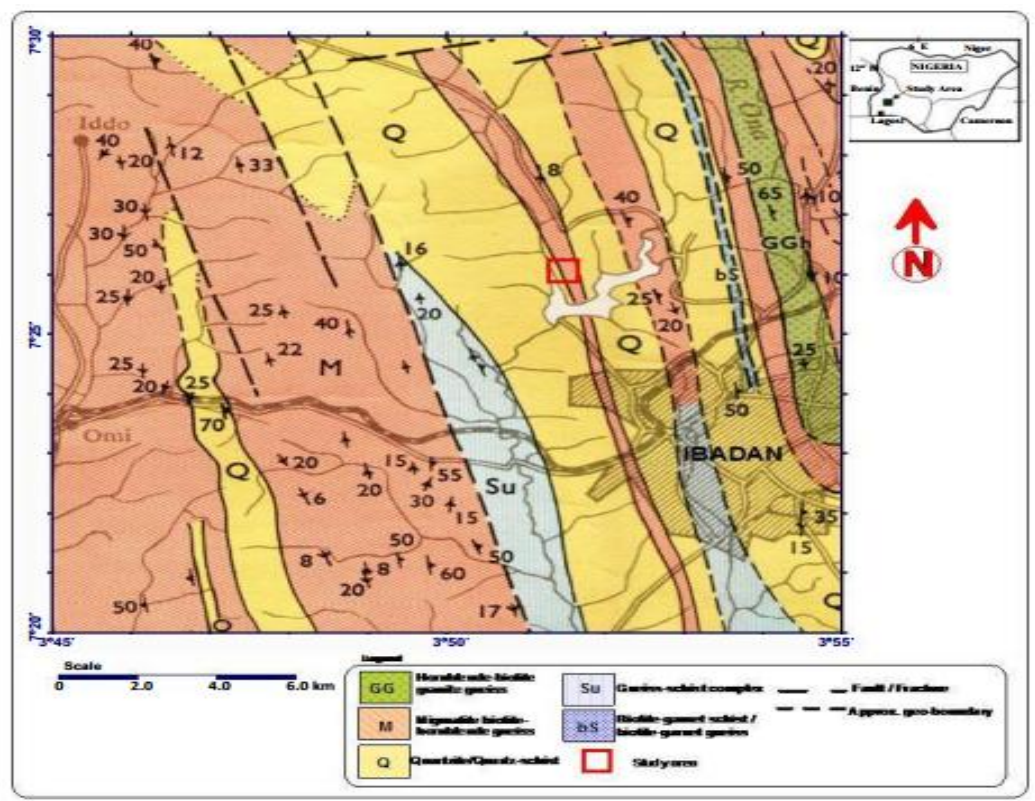

Fig. 1: Geological map of Ibadan showing the study area (Oladunjoye et al. 2013). 


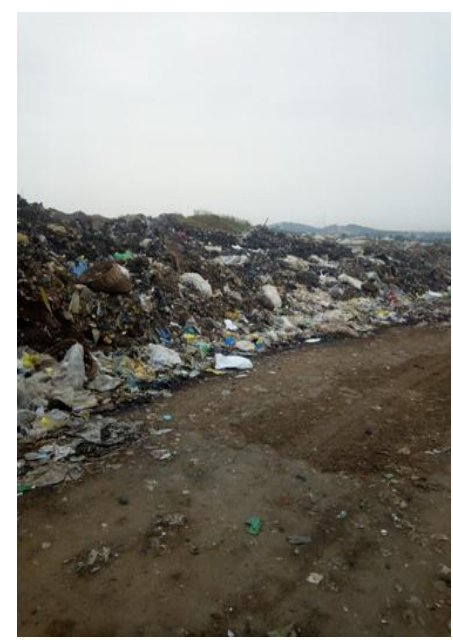

$\mathbf{a}$

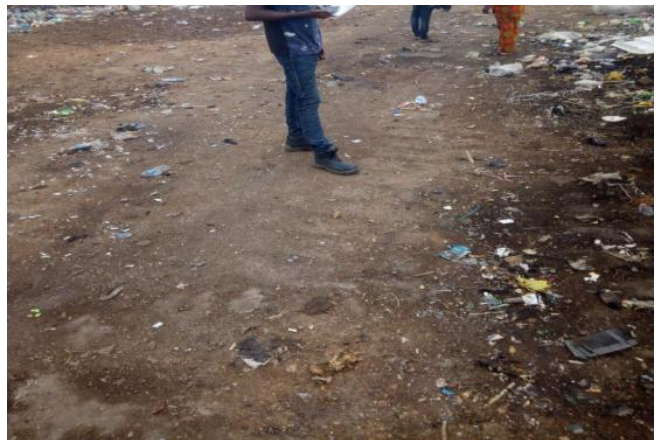

b

Fig. 2: Awotan dumpsite areas.

and its tributaries. The area is usually well-drained during the rainy season but the tributaries dry up during the dry season. The main rock types underlying the dumpsite belong to the Migmatite-gneiss-quartzite complex (Rahaman 1976, 1988) consisting of quartz, schist and migmatite gneiss, while pegmatite and quartz occur as veins in the major rocks (Fig. 1). The quartz schist and the biotite gneiss trend North-South direction and are variously jointed. The quartz schist covers more than $60 \%$ of the area while migmatite gneiss covers the remaining $40 \%$ area. The migmatite gneiss occurs mainly as low-lying outcrops while the quartz schist forms ridges.

\section{MATERIALS AND METHODS}

\section{Study Area}

The Awotan dumpsite is located between Latitudes $7^{\circ} 27.59^{\prime} \mathrm{N}$ and $7^{\circ} 27.73^{\prime} \mathrm{N}$ and Longitudes $3^{\circ} 50.93^{\prime} \mathrm{E}$ and $3^{\circ} 51.17^{\prime} \mathrm{E}$ and found along Awotan-Akufo Road, Apete area of Ibadan Metropolis, Southwestern Nigeria (Fig. 2). The Awotan area has a unique environmental setting characterized by a wide range of land-use activities such as small scale arable farming, animal husbandry, residential and commercial settlements. Leachate emanating from the wastes is washed down into the surrounding areas thereby impacting the soils within the area.

\section{Sample Collection}

Ten (10) soil samples were collected for this study. Sampling was done at regular intervals with the aid of an auger at a depth of $0-30 \mathrm{~cm}$. The soil samples were stored in plastic bags and labelled according to the location at which they were collected. The sampling points are presented in Fig. 3. Each sample was immediately placed in a plastic bag and tightly sealed to avoid contamination from the environment and transportation.

\section{Sample Analysis}

The heavy metals were analysed by the inductively coupled plasma mass spectrometry (ICP-MS) and X-Ray fluorescence spectrometry (XRF) methods. Ten soil samples were analysed by Laser ablation microprobe Inductivity Coupled Plasma-Mass Spectrometry (La ICP-MS) method (Jackson et al. 1992) at the Central laboratory of the Stellenbosch University, South Africa. The ICP-MS instrument is Perkin-Elma Sciex ELAN 5100 coupled with a UV $(266 \mu \mathrm{m})$

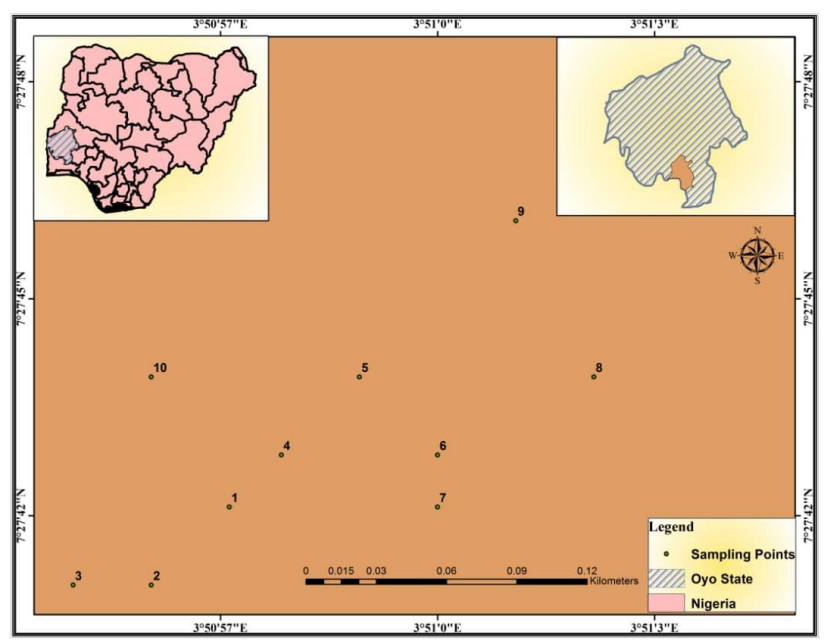

Fig. 3: Map of the study area. 
laser. The laser was operated with $1 \mathrm{~mJ} /$ Pulse energy and $4 \mathrm{~Hz}$ frequency for carbonates and silicate glass. The spot diameter for these analyses is $30-50 \mathrm{~m}$. NIST 610 glass was used as a calibration standard for all the samples with ${ }^{44} \mathrm{Ca}$ as an internal standard. The analytical precision is $5 \%$ at the ppm level. Details of ICP-MS and laser operating conditions have been published by Norman et al. (1996) and Norman (1998). The results of the compositions of the heavy metals are presented in Table 1.

\section{RESULTS AND DISCUSSION}

The variations in the concentrations of each heavy metal across the sampling points showed the following ranges: $\mathrm{Cu}$ (43.71-469.64) with a mean of $113.74 \mathrm{mg} / \mathrm{kg}, \mathrm{Zn}(53.50-$ $615.60)$ with a mean of $130.52 \mathrm{mg} / \mathrm{kg}, \mathrm{Rb}(83.14-225.35)$ with a mean value of $145.37 \mathrm{mg} / \mathrm{kg}$ and $\mathrm{Pb}(28.38-209.15)$ with a mean of $68.01 \mathrm{mg} / \mathrm{kg}$. The concentration of some heavy metals in the soil of the dumpsite is presented in descending order as $\mathrm{Zn}>\mathrm{Cu}>\mathrm{Rb}>\mathrm{Pb}>\mathrm{V}$.

\section{Methods of Assessment of Contamination in Dumpsite Soil}

Contamination indices used to assess the heavy metal contamination levels in the soil around the dumpsite include the enrichment factor (Ef), contamination factor (Cf), geo-accumulation index (Igeo), pollution load index (PLI), degree of contamination $(\mathrm{Cd})$, and ecological risk index. (Er).

\section{Enrichment Factor}

The computation of enrichment factor $(\mathrm{EF})$ has been adopted to evaluate the impact of anthropogenic and naturally occurring sources of heavy metals as well as the metal abundance in soil. Yongming (2006) stated that EF has been used to determine the degree of modification in the composition of heavy metals in the area of atmospheric aerosols, sediments, soil and solid wastes. The EF of metals has been defined using Scandium (Sc) as a natural element of reference.

$$
\mathrm{EF}=\frac{\mathrm{Cx}(\text { sample }) / \text { Cref(sample })}{\mathrm{Bn}(\text { background }) / \text { Bref(background })}
$$

Where, Cx (sample) is the concentration of the element in the examined environment and $\mathrm{C}_{\text {ref }}$ (sample) is the concentration of the reference element for normalization, Bx(background) is the concentration of the element in the crust, and $\mathrm{B}_{\text {ref }}$ is the concentration of the reference element used for the normalization in the crust (Ato et al. 2010, Cevik 2009). Five contamination categories have been suggested based on enrichment factor where $\mathrm{EF}<2$ = minor enrichment; $\mathrm{EF}$ $=2-5=$ moderate enrichment EF $=5-20=$ significant enrichment; $\mathrm{EF}=20-40$ = very high enrichment; and $\mathrm{EF}>40$ extremely high enrichment (Yongming 2006). The maximum enrichment factors shown in Table 2 in decreasing values are 25.07 for $\mathrm{Cu}$, (very high enrichment), 18.78 for $\mathrm{Pb}$ and 15.14 for $\mathrm{Zn}$ (significant enrichment), 2.05 for Mo (moderate enrichment) and $\mathrm{Co}, \mathrm{Ni}, \mathrm{Rb}$ and $\mathrm{Cs}$ have minor enrichment since they are less than two (2) (Birch 2003).

Table 1: Heavy metal concentration $(\mathrm{mg} / \mathrm{kg})$ in soil obtained from the dumpsites.

\begin{tabular}{|lllllllllll|}
\hline Sampling point & $\mathrm{Sc}$ & $\mathrm{V}$ & $\mathrm{Co}$ & $\mathrm{Ni}$ & $\mathrm{Cu}$ & $\mathrm{Zn}$ & $\mathrm{Rb}$ & $\mathrm{Mo}$ & $\mathrm{Cs}$ & $\mathrm{Pb}$ \\
\hline 1 & 11.35 & 70.34 & 16.92 & 46.55 & 469.64 & 615.60 & 122.65 & 2.72 & 4.18 & 164.39 \\
2 & 11.10 & 70.95 & 15.95 & 28.85 & 52.00 & 81.30 & 138.35 & 1.56 & 4.39 & 39.02 \\
3 & 13.02 & 87.78 & 21.27 & 38.95 & 64.65 & 77.95 & 158.95 & 1.72 & 4.48 & 50.69 \\
4 & 18.47 & 137.30 & 28.79 & 57.50 & 53.43 & 72.35 & 151.65 & 2.39 & 6.29 & 41.75 \\
5 & 21.86 & 165.85 & 26.67 & 65.95 & 61.20 & 91.85 & 186.81 & 2.73 & 7.82 & 34.76 \\
6 & 18.19 & 130.64 & 17.45 & 52.95 & 64.72 & 101.25 & 225.35 & 1.97 & 7.79 & 28.38 \\
7 & 17.70 & 115.50 & 16.99 & 46.60 & 59.90 & 88.75 & 182.65 & 1.95 & 7.43 & 31.84 \\
8 & 21.25 & 131.30 & 16.09 & 42.00 & 43.71 & 53.50 & 83.14 & 2.45 & 4.99 & 39.09 \\
9 & 19.94 & 122.95 & 17.04 & 42.35 & 123.36 & 60.05 & 98.04 & 2.65 & 4.48 & 41.03 \\
10 & 19.82 & 166.07 & 47.89 & 42.75 & 144.80 & 62.60 & 106.08 & 1.46 & 4.12 & 209.15 \\
Min & 11.10 & 70.34 & 15.95 & 28.85 & 43.71 & 53.50 & 83.14 & 1.46 & 4.12 & 28.38 \\
Max & 21.86 & 166.07 & 47.89 & 65.95 & 469.64 & 615.60 & 225.35 & 2.73 & 7.82 & 209.15 \\
Mean & 17.27 & 119.87 & 22.50 & 46.45 & 113.74 & 130.52 & 145.37 & 2.16 & 5.59 & 68.01 \\
SD & 4.00 & 34.49 & 10.02 & 10.33 & 129.34 & 171.10 & 44.66 & 0.49 & 1.57 & 63.76 \\
\hline
\end{tabular}


Table 2: Average, min and max values of Enrichment Factor.

\begin{tabular}{|c|c|c|c|c|c|c|c|c|c|}
\hline & V & $\mathrm{Co}$ & $\mathrm{Ni}$ & $\mathrm{Cu}$ & $\mathrm{Zn}$ & $\mathrm{Rb}$ & Mo & $\mathrm{Cs}$ & $\mathrm{Pb}$ \\
\hline Average & 0.65 & 0.85 & 0.79 & 3.63 & 2.12 & 0.91 & 0.76 & 0.92 & 3.24 \\
\hline Min & 0.57 & 0.33 & 0.38 & 0.49 & 0.20 & 0.11 & 0.50 & 0.27 & 0.91 \\
\hline Max & 0.82 & 1.16 & 1.63 & 25.07 & 15.14 & 1.43 & 2.05 & 1.33 & 18.78 \\
\hline SD & 0.07 & 0.26 & 0.32 & 7.59 & 4.58 & 0.40 & 0.47 & 0.27 & 5.51 \\
\hline
\end{tabular}

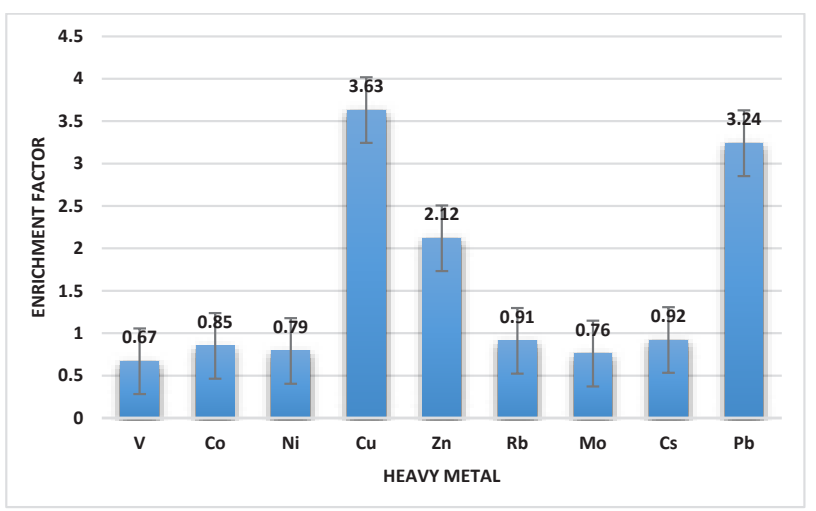

Fig. 4: Average enrichment of $\mathrm{Cu}, \mathrm{Pb}$ and $\mathrm{Zn}$.

Fig. 4 presents the histogram of the average enrichment of $\mathrm{Cu}, \mathrm{Pb}$ and $\mathrm{Zn}$ along with the other heavy metals in the soil. The very high and significant enrichment of $\mathrm{Cu}, \mathrm{Pb}$ and $\mathrm{Zn}$ is an initial indication of an anthropogenic influence of the metals in the soil.

\section{Contamination Factor (CF)}

Contamination factor is a quantification of the degree of contamination relative to either the average crustal composition of a respective metal or to the measured background values from a geologically similar and uncontaminated area (Tijani et al. 2004). It is expressed in equation 2 given by Hakanson (1980) as:

$$
C_{F}=C_{x} / B_{m}
$$

Where, $\mathrm{Cx}$ and $\mathrm{Bm}$ are the concentrations of metal in a soil sample and background environments. The background values of heavy metals were taken from Taylor and McLennan (1995). The CF is classified into four groups ( $\mathrm{CF}<1$; indicates low metal contamination), $(1 \leq \mathrm{CF}<3$; indicates moderate contamination), $(3 \leq \mathrm{CF} \leq 6$; indicates considerable contamination), and ( $\mathrm{CF}>6$ indicates very high contamination) (Hakanson 1980).

The results of the contamination factor $(\mathrm{CF})$ for the heavy metals are presented in Table 3. The results show that $\mathrm{Cu}$ ranges from 0.53 to $23.02 \mathrm{mg} / \mathrm{kg}$ with a mean value of 3.90 $\mathrm{mg} / \mathrm{kg}, \mathrm{Zn}$ varies from 0.38 to $12.37 \mathrm{mg} / \mathrm{kg}$ with a mean of 1.98 while $\mathrm{Pb}$ varies between 1.12 and $15.35 \mathrm{mg} / \mathrm{kg}$ with a mean value of $363.72 \mathrm{mg} / \mathrm{kg}$ with a mean of 3.22 . Going by the groupings and using the mean values $\mathrm{V}, \mathrm{Ni}$ and $\mathrm{Mo}$ have values that are less than one showing low contamination $(\mathrm{CF}<1)$. Sc, Co, Zn, Rb, Cs have values that are more than 1 and less than three $(1<\mathrm{CF}<3)$ thus indicating moderate contamination. $\mathrm{Cu}$ and $\mathrm{Pb}$ have values that are more than 3

Table 3: Contamination factors, (CF), PLI and mCd.

\begin{tabular}{|c|c|c|c|c|c|c|c|c|c|c|c|c|}
\hline Sample no & $\mathrm{Sc}$ & $\mathrm{V}$ & Co & $\mathrm{Ni}$ & $\mathrm{Cu}$ & $\mathrm{Zn}$ & $\mathrm{Rb}$ & Mo & Cs & $\mathrm{Pb}$ & PLI & $\mathrm{mCd}$ \\
\hline 1 & 0.82 & 0.41 & 0.93 & 1.33 & 23.02 & 12.37 & 0.94 & 0.17 & 0.69 & 15.35 & 1.69 & 5.60 \\
\hline 2 & 0.91 & 0.37 & 0.86 & 0.52 & 0.53 & 0.72 & 0.82 & 0.05 & 0.99 & 1.12 & 0.55 & 0.69 \\
\hline 3 & 0.81 & 0.42 & 0.83 & 0.64 & 2.12 & 0.99 & 1.16 & 0.08 & 0.77 & 2.81 & 0.77 & 1.06 \\
\hline 4 & 1.21 & 0.55 & 1.40 & 0.91 & 1.09 & 0.64 & 1.11 & 0.06 & 1.03 & 2.24 & 0.79 & 1.02 \\
\hline 5 & 1.64 & 0.97 & 1.63 & 1.37 & 1.59 & 0.89 & 1.04 & 0.12 & 1.48 & 1.93 & 1.06 & 1.27 \\
\hline 6 & 1.69 & 0.87 & 1.19 & 1.30 & 1.47 & 1.05 & 1.62 & 0.09 & 1.65 & 1.55 & 1.03 & 1.25 \\
\hline 7 & 1.12 & 0.58 & 0.65 & 0.81 & 1.77 & 1.07 & 1.60 & 0.06 & 1.46 & 1.32 & 0.81 & 1.04 \\
\hline 8 & 1.59 & 0.71 & 1.14 & 1.05 & 1.24 & 0.80 & 1.00 & 0.09 & 1.52 & 1.85 & 0.90 & 1.10 \\
\hline 9 & 1.70 & 0.75 & 0.56 & 0.64 & 0.94 & 0.38 & 0.18 & 0.11 & 0.45 & 2.08 & 0.56 & 0.78 \\
\hline 10 & 1.36 & 0.62 & 1.23 & 1.06 & 5.23 & 0.90 & 1.22 & 0.09 & 1.34 & 1.99 & 1.04 & 1.50 \\
\hline Mean & 1.28 & 0.62 & 1.04 & 0.96 & 3.90 & 1.98 & 1.07 & 0.09 & 1.14 & 3.22 & 0.92 & 1.53 \\
\hline Max & 1.70 & 0.97 & 1.63 & 1.37 & 23.02 & 12.37 & 1.62 & 0.17 & 1.65 & 15.35 & 1.69 & 5.98 \\
\hline Min & 0.81 & 0.37 & 0.56 & 0.52 & 0.53 & 0.38 & 0.18 & 0.05 & 0.45 & 1.12 & 0.55 & 0.50 \\
\hline
\end{tabular}




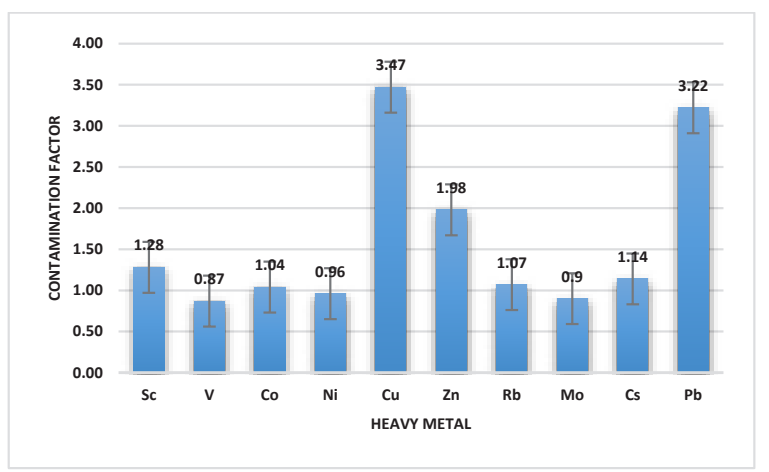

Fig. 5: Histogram of contaminating heavy metals.

and less than 6 indicating high contamination. Fig. 5 presents a picture of the contaminating heavy metals. It should be noted that sampling site one (1) has high contaminations of $\mathrm{Cu}$ (23.02), $\mathrm{Zn}$ (12.37) and $\mathrm{Pb}$ (15.35) respectively. The modified degree of contamination $(\mathrm{mCd})$ expressed in Fig. 6 agrees with the contamination levels at site one (1) with a value of 5.60 (Table 3 ).

\section{Geo-accumulation Index (Igeo)}

The geo-accumulation index of (Igeo) is widely used to measure the level of pollution caused by heavy metals in the soil. The $\mathrm{I}_{\text {geo }}$ values were calculated using equation 3 first proposed by Muller (1969) as:

$$
I_{\text {geo }}=\log _{2}\left[\frac{C x}{1.5 B_{n}}\right]
$$

Where, Cx represents the measured concentration of the elements studied and $\mathrm{Bn}$ is the geochemical background value of the element or average shale (Taylor \& McLennan 1985). The constant 1.5 takes care of changes in the concentration of the heavy metals in the environment (Wei \& Yang 2010, Loska 2004) grouped Igeo as Igeo $\leq 0=$ no pollution; Igeo (0-1), moderate pollution; Igeo (1-2), strong pollution; Igeo (2-3), high pollution; Igeo (3-4), very high

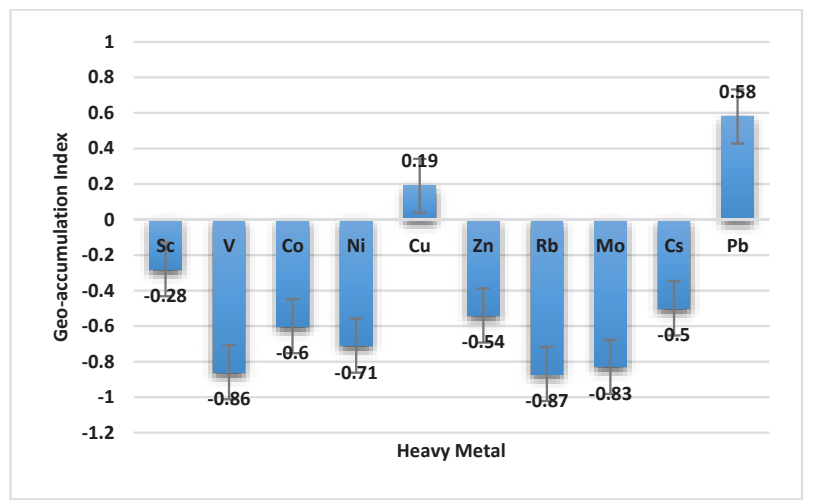

Fig.7: Average geo-accumulation of the heavy metals.

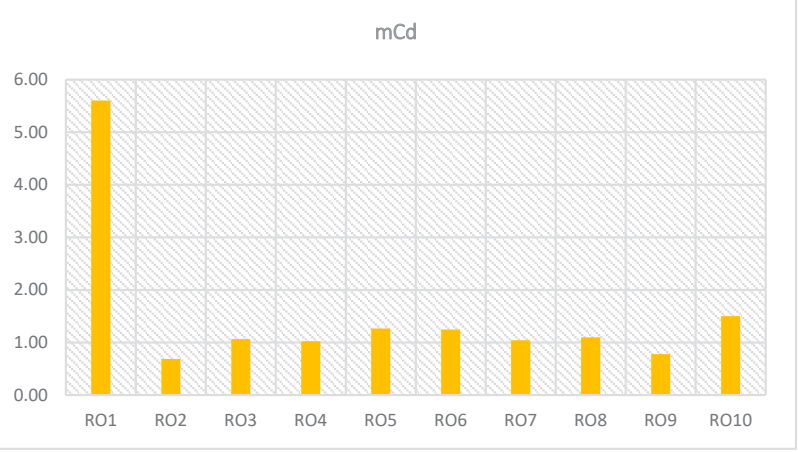

Fig. 6: Histogram of the modified degree of contamination (mCd).

pollution; Igeo (4-5) severe pollution and Igeo ( $>5$ ) extreme pollution. The results of Igeo indicated that $\mathrm{Cu}$ and $\mathrm{Pb}$ are positive (Fig.7) in contrast to the other metals suggesting some anthropogenic influences of these heavy metals in the study area. The $\mathrm{Cu}$ (3.77), $\mathrm{Zn}$ (3.04), and $\mathrm{Pb}$ (3.35) at site one (1) have values that are more than 3, Igeo (3-4), indicating very high pollution in the soil and tandem with (Fig.6) $\mathrm{mCd}$. Similarly, $\mathrm{Cu}$ alone at site ten (10) has a value of 1.63, Igeo (1-2), thereby showing strong pollution.

\section{Ecological Risk Assessment (RI).}

The ecological risk index (RI) evaluates the potential ecological risk of heavy metals in the sediment /soil as suggested by Hakanson (1980) in Equation 4.

$$
\mathrm{RI}=\mathrm{CFn} \times \mathrm{T}_{\mathrm{R}}
$$

Where, $\mathrm{C}_{\mathrm{Fn}}$ and $\mathrm{T}_{\mathrm{R}}$ are $\mathrm{CF}$ and the toxicological response factor of individual heavy namely $\mathrm{Cu}(5), \mathrm{Zn}$ (1) $\mathrm{Ni}(5)$ and $\mathrm{Pb}$ (5) (Hakanson 1980, Kumar et al. 2018). In a way to know the ecological risks of anthropogenic and lithogenic influences, the CFn in the RI is replaced by computation with EF. The ecological RI worked out from EF is the modified potential ecological index MPI (Kumar et al. (2018) written as in Equation 5.

$$
\mathrm{MPI}=\mathrm{EFn} \times \mathrm{Tr}
$$

Where, EFn and Tr are the EF and the toxicological response factor of individual heavy metals respectively. The classes used for risk assessment are as follows:

$\mathrm{Er}<40$ (low risk); 40- 80 (moderate risk); 80 -160 (considerable risk); 160-320 (high risk) and > 320 (very high risk). In the case of risk index, (equation 5) RI $<95$ indicates a low potential ecological risk; 95-190 moderate risk; $190-380$ considerable risk while $\mathrm{RI}>380$ very high risk.

The ecological risks of $\mathrm{Ni}, \mathrm{Cu}, \mathrm{Zn}$ and $\mathrm{Pb}$ were assessed using the potential ecological risk index RI (Fig. 8) and the modified potential ecological risk index MRI (Fig. 9). 


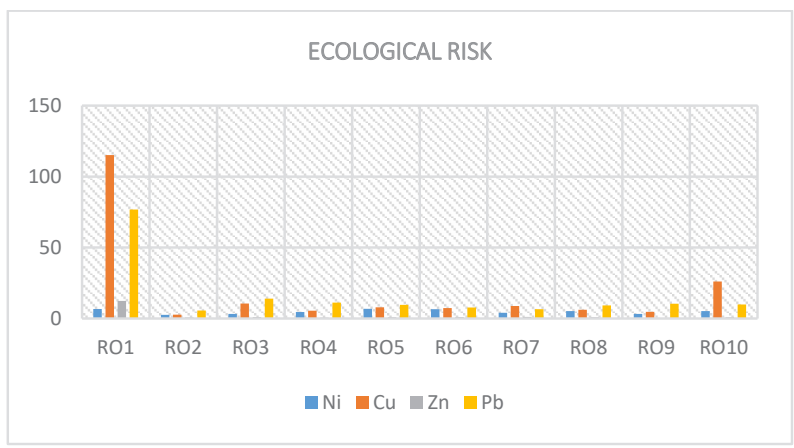

Fig. 8: The ecological risk factor (RI) for $\mathrm{Ni}, \mathrm{Cu}, \mathrm{Zn}$ and $\mathrm{Pb}$ in each sample sites.

The results in Table 4 revealed that Er values for $\mathrm{Cu}$ and $\mathrm{Zn}$ are less than $40(\mathrm{Er}<40)$ respectively indicating low ecological risk of these heavy metals. $\mathrm{Cu}$ and $\mathrm{Pb}$ have varying values. Sampling sites from 2 to 10 have values that are less than 40 showing low ecological risks by these heavy metals, however, site one (1) has the value of 115.10 for $\mathrm{Cu}$ and 76.74 for $\mathrm{Pb}$ indicating considerable risks (Er 80-160) and moderate risk (Er 40- 80) respectively. The results of MRI revealed that about $62.53 \%$ of sample site one showed a considerable ecological risk of the heavy metal $\mathrm{Cu}$ and $47.61 \%$ of the moderate ecological risk of $\mathrm{Pb}$ respectively

\section{Assessment of Ecological Risks}

The variation in the ecological risk index of the heavy metals across the sampling sites is presented in Fig. 9. The relatively considerable ecological risk index recorded for $\mathrm{Cu}$ and moderate ecological risk of $\mathrm{Pb}$ respectively at sampling sites one (1) suggests an anthropogenic source of $\mathrm{Cu}$ and $\mathrm{Pb}$ in this part of the study area.

Table 4: Ecological risk factor for nickel, copper, zinc and lead.

\begin{tabular}{|lllll|}
\hline Sample no. & $\mathrm{Ni}$ & $\mathrm{Cu}$ & $\mathrm{Zn}$ & $\mathrm{Pb}$ \\
\hline 1. & 6.65 & 115.10 & 12.37 & 76.74 \\
2. & 2.61 & 2.65 & 0.72 & 5.61 \\
3. & 3.20 & 10.61 & 0.99 & 14.04 \\
4. & 4.56 & 5.46 & 0.64 & 11.18 \\
5. & 6.87 & 7.94 & 0.89 & 9.66 \\
6. & 6.50 & 7.35 & 1.05 & 7.73 \\
7. & 4.04 & 8.83 & 1.07 & 6.62 \\
8 & 5.23 & 6.21 & 0.80 & 9.26 \\
9. & 3.21 & 4.71 & 0.38 & 10.41 \\
10. & 5.28 & 26.13 & 0.90 & 9.93 \\
TR & 5 & 5 & 1 & 5 \\
Mean & 4.815 & 19.4975 & 1.980579 & 16.1175 \\
Ranges & $2.61-6.65$ & $2.65-115.10$ & $0.38-12.37$ & $6.67-76.74$ \\
\hline
\end{tabular}

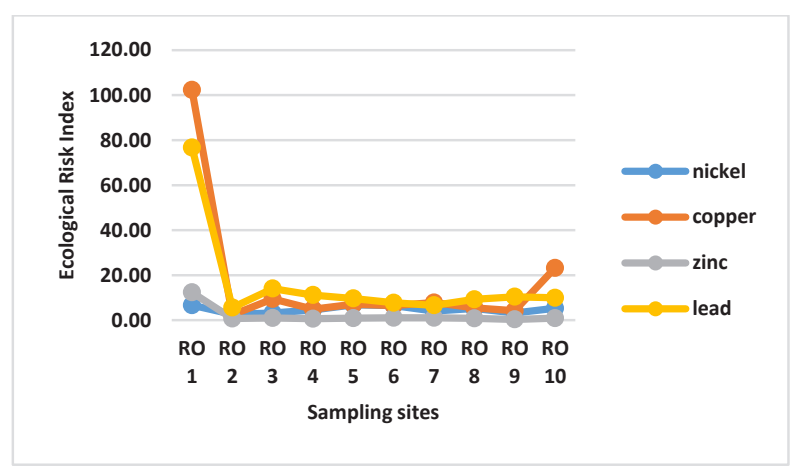

Fig. 9: Modified potential ecological risk index (MRI).

\section{HEALTH RISK ASSESSMENT}

Health risk assessment in this study is a way to determine the probable level of the harmful health impacts of heavy metals on the soil. The assessment of each metal contaminant is based on the level of risk of using the soil and it is classified as carcinogenic or non-carcinogenic health hazards (Wongsasuluk et al. 2014). Hazard quotients (HQ), Hazard index (HI), are used in the calculation of the potential carcinogenic and non-carcinogenic health risk caused through ingestion and dermal absorption of heavy metals in the soil by adults. HQ (for each heavy metal) is the ratio of an average daily intake (ADI, $\mathrm{mg} / \mathrm{kg} /$ day) of metal ingested to the reference oral dose (RfD) through oral ingestion and dermal absorption for the adult residents around the environment. ADI (mg/ kg-day) for the different pathways were calculated using the exposure equations (6) and (7) (USEPA 2012).

\section{Ingestion of Heavy Metals through Soil}

$$
\mathrm{ADI}_{\text {ing }}=\frac{c \times \operatorname{Ring} \times C F \times E D}{B W \times A T}
$$

Where, $\mathrm{ADI}_{\text {ingestion }}$ is the average daily intake of heavy metals ingested from the soil in $\mathrm{mg} / \mathrm{kg}$-day, $\mathrm{C}=$ concentration of heavy metal in $\mathrm{mg} / \mathrm{kg}$ for soil. IR in $\mathrm{mg} /$ day is the ingestion rate, $\mathrm{EF}$ in days/year is the exposure frequency, $\mathrm{ED}$ is the exposure duration in years, BW is the bodyweight of the exposed individual in $\mathrm{kg}$, AT is the time over which the dose is averaged in days. $\mathrm{CF}$ is the conversion factor in $\mathrm{kg} / \mathrm{mg}$.

\section{Inhalation of Heavy Metals Via Soil Particulates}

$$
\mathrm{ADI}_{\text {inh }}=\frac{c \times R \operatorname{Rinh} \times E F \times E D}{P E F \times B W \times A T}
$$

Where $\mathrm{ADI}_{\mathrm{inh}}$ is the average daily intake of heavy metals inhaled from the soil in $\mathrm{mg} / \mathrm{kg}$-day, CS is the concentration of heavy metal in the soil in $\mathrm{mg} / \mathrm{kg}$, IRair is the inhalation rate in $\mathrm{m} 3 / \mathrm{day}, \mathrm{PEF}$, is the particulate emission factor in 
$\mathrm{m} 3 / \mathrm{kg}$. EF, ED, BW and AT are as defined earlier in Equation (7) above.

\section{Dermal Contact with Soil}

$$
\mathrm{ADI}_{\text {dems }}=\frac{c \times S A \times C F \times S L \times A B S \times E D}{B W \times A T}
$$

Where $\mathrm{ADI}_{\mathrm{dems}}$ is the exposure dose via dermal contact in $\mathrm{mg} / \mathrm{kg} /$ day. CS is the concentration of heavy metal in the soil in $\mathrm{mg} / \mathrm{kg}$, SA is exposed skin area in $\mathrm{cm}^{2}, \mathrm{FE}$ is the fraction of the dermal exposure ratio to the soil, AF is the soil adherence factor in $\mathrm{mg} / \mathrm{cm}^{2}, \mathrm{ABS}$ is the fraction of the applied dose absorbed on the skin. EF, ED, BW, CF and AT are as defined earlier in Equation (8).

\section{Non-Carcinogenic Risk}

The results for ingestion, inhalation and dermal pathways presented in Table 5 indicated that HI values for ingestion pathways and dermal pathways are $9.84636 \times 10^{-5}$ and
$7.85357 \times 10^{-7}$ respectively implying that the values are less than one $(\mathrm{HI}<1)$ and no obvious risks.

The HI value for ingestion is greater than that of the dermal pathway indicating that the ingestion pathway contributes the greatest non-carcinogenic effect. The inhalation pathway is the least contributor (Fig. 10). Sultana et al. (2019) suggested that when $\mathrm{HI}>1$ there is the possibility that non-carcinogenic impacts may occur in the adult residents whereas when $\mathrm{HI}<1$ it is expected that the exposed person may not experience noticeable harmful health impacts.

\section{Carcinogenic Risk}

The results of the carcinogenic risk calculated for heavy metals are presented in Table 6 . Pb is singled out for carcinogenic health risk assessment because of its toxicity and its known CSF. The cancer slope factor is defined as the risk generated by a lifetime average amount of one $\mathrm{mg} / \mathrm{kg} / \mathrm{day}$ of carcinogen around the sampled area. Table 6 indicated that

Table 5: The Hazard Index (HI) of some selected heavy metals.

\begin{tabular}{|llllll|}
\hline & $\mathrm{Pb}$ & $\mathrm{Ni}$ & $\mathrm{Cu}$ & $\mathrm{Zn}$ & \multicolumn{1}{l|}{$\mathrm{HI}$} \\
\hline HQ ingestion (ing) & $7.01 \mathrm{E}-05$ & $9.42 \mathrm{E}-06$ & $1.65 \mathrm{E}-05$ & $2.45473 \mathrm{E}-06$ & - \\
HQ inhalation (inh) & - & - & - & $2.9 \mathrm{E}-07$ & $1.11936 \mathrm{E}-07$ \\
HQ dermal & - & $3.83 \mathrm{E}-07$ & - & - & - \\
Risk pathway ing & $2.14 \mathrm{E}-09$ & - & - & - & - \\
Risk pathway inh & $2.81 \mathrm{E}-10$ & - & - & - \\
Risk Total & $2.43 \mathrm{E}-09$ & - & - & - \\
\hline
\end{tabular}

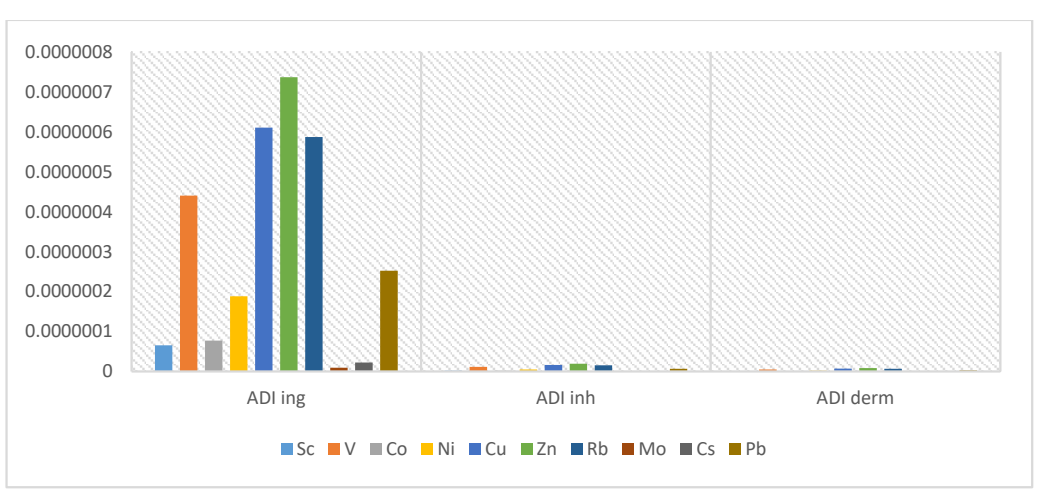

Fig.10: Histogram of heavy metals in different pathways.

Table 6: Average daily intake (ADI) of heavy metals in the sampled soil.

\begin{tabular}{|llllllllllll}
\hline & $\mathrm{Sc}$ & $\mathrm{V}$ & $\mathrm{Co}$ & $\mathrm{Ni}$ & $\mathrm{Cu}$ & $\mathrm{Zn}$ & $\mathrm{Rb}$ & $\mathrm{Mo}$ & $\mathrm{Cs}$ & $\mathrm{Pb}$ \\
\hline $\begin{array}{l}\text { ADI } \\
\text { ingestion }\end{array}$ & $6.54 \mathrm{E}^{-08}$ & $4.4 \mathrm{E}^{-07}$ & $7.74 \mathrm{E}-08$ & $1.88356 \mathrm{E}-07$ & $6.10489 \mathrm{E}-07$ & $7.36419 \mathrm{E}-07$ & $5.87 \mathrm{E}-07$ & $9.23 \mathrm{E}-09$ & $2.23 \mathrm{E}-08$ & $2.52329 \mathrm{E}-07$ \\
$\begin{array}{l}\text { ADI } \\
\text { inhalation }\end{array}$ & $1.73 \mathrm{E}-09$ & $1.17 \mathrm{E}-08$ & $2.05 \mathrm{E}-09$ & $4.9859 \mathrm{E}-09$ & $1.616 \mathrm{E}-08$ & $1.94934 \mathrm{E}-08$ & $1.55 \mathrm{E}-08$ & $2.44 \mathrm{E}-10$ & $5.9 \mathrm{E}-10$ & $6.67929 \mathrm{E}-09$ \\
ADI dermal & $7.45 \mathrm{E}-10$ & $5.02 \mathrm{E}-09$ & $8.83 \mathrm{E}-10$ & $2.14726 \mathrm{E}-09$ & $6.95958 \mathrm{E}-09$ & $8.39517 \mathrm{E}-09$ & $6.69 \mathrm{E}-09$ & $1.05 \mathrm{E}-10$ & $2.54 \mathrm{E}-10$ & $2.87655 \mathrm{E}-09$ \\
\hline
\end{tabular}


the values of the heavy metals are less than one meaning that it is below the generally acceptable value which Tepanosyan (2017) suggested should be $1 \times 10^{-6}$ for a single carcinogenic element and $1 \times 10^{-4 \mathrm{f}}$ for multi-element carcinogens. The value $2.43 \times 10^{-9}$ is less than the acceptable value implying a negligible cancer risk for the soils of the dumpsites.

\section{CONCLUSIONS}

The ecological and health risks of some heavy metals of dumpsites at Wotan, Ibadan were studied. The results of the enrichment factor indicated a very high enrichment of $\mathrm{Cu}$ (25.07), and 15.14 significant enrichment of $\mathrm{Pb}$ (18.78), moderate enrichment of $\mathrm{Zn}$ (15.14) and minor enrichment of $\mathrm{Co}, \mathrm{Ni}, \mathrm{Rb}$ and $\mathrm{Cs}$. The very high, significant and moderate enrichments of $\mathrm{Cu}, \mathrm{Pb}$ and $\mathrm{Zn}$ are an initial indication of an anthropogenic influence of the metals in the soil. V, Ni and Mo have shown low contamination. Sc, Co, Zn, Rb, Cs indicated moderate contamination while $\mathrm{Cu}$ and $\mathrm{Pb}$ indicated high contamination. It should be noted that sampling site one (1) has high contaminations of $\mathrm{Cu}$ (23.02), $\mathrm{Zn}$ (12.37) and $\mathrm{Pb} . \mathrm{Cu}$ and $\mathrm{Pb}$ exhibited high contamination levels. The relatively considerable ecological risk index recorded for $\mathrm{Cu}$ and moderate ecological risk of $\mathrm{Pb}$ respectively at sampling sites one (1) suggests an anthropogenic source of $\mathrm{Cu}$ and $\mathrm{Pb}$ in this part of the study area. The health-risk study indicated that hazard quotient $\mathrm{HQ}_{\text {ing }}, \mathrm{HQ}_{\text {derm }}$ and hazard index (HI) values were below the acceptable limits of $1 \times 10^{-6}$ and $1 \times 10^{-4}$ and therefore showed no obvious non-carcinogenic risk and negligible cancer risk from the soils on health and environment.

\section{REFERENCES}

Aderinola, O.J., Clarke, E.O., Olarinmoye, O.M., Kusemiju, V. and Anatekhai, M.A. 2009. Heavy metals in surface water, sediments, fish and perwinkles of Lagos lagoon. American-Eurasian J. Agric. \& Environ. Sci., 5 (5): 609-617.

Ato, A.F., Samuel, O., Oscar, Y.D., Alex, P., Moi, N. and Akoto, B. 2010. Mining and heavy metal pollution assessment of aquatic environments in Tarkwa, Ghana using multivariate statistical analysis. Journal of Environmental Statistics, 1(4): 1-13.

Bazrafshan, E., Leli, M., Alireza, A.M. and Amir, H.M. 2015. Heavy metal removal from aqueous environments by electrocoagulation process- a systematic review. Journal of Environmental Health Science and Engineering, 13(1): 1-16.

Birch, G. and Woodroffe, F. 2003. Coastal GIS 2003, Wolloongong University Papers in Center of Maritime Policy, 14, Australia, Edition Edn.

Cevik, F., Goksu, M. Z.L., Derici, O.B. and Findik, O. 2009. An assessment of metal pollution in surface sediments of Seyhan dam by using enrichment factor, geo-accumulation index and statistical analyses. Environmental Monitoring and Assessment, 152(1-4): 309-317.

Dorne, J., Kass, G., Bordajandi, L.R., Amzal, B., Bertelsen, U., Castoldi, A.F., Heppner, C., Eskola, M., Fabiansson, S. and Ferrari, P. 2011. Human risk assessment of heavy metals: Principles and applications. Met. Ions Life Sci., 8: 159-171.
Hakanson, L. 1980. Ecological risk index for aquatic pollution control, a sedimentological approach. Water Research, 14(8): 975-1001.

Hu, Z., Yang, Z., Liang, X., Salakhutdino, V. and Xing, E.P. 2017. On unifying deep generative models arxiv preprint arxiv 1706. 00550 3-10.

Ileoje, N.P. 1987. A New Geography of Nigeria. Longman Nigeria Limited, Ikeja, pp. 201.

Jackson, S.E., Longerich, H.P., Dunning, G.R and Fryer, B.J. 1992. The application of Laser- ablation micro- probe-inductively coupled plasma-mass spectrometry (LAM-ICP-MS) to in situ trace element determination in minerals. Canadian Mineralogist 30, 1049-1064.

Kamunda, C., Mathuthu, M. and Madhuku, M. 2016. Health risk assessment of heavy metals in soils from Witwatersrand gold mining basin, South Africa. Int. J. Environ. Res. Public Health, 13: 663.

Kumar, V., Sharma A., Minakshi, S. 2018. Temporal distribution, source apportionment, and pollution assessment of metals in the sediments of Beas river, India. Hum Ecol Risk Assess 5: 1-20. Doi.org/10.1080 /10807039.2018.144052

Loska, K., Wiechula, D. and Korus, I. 2004. Metal contamination of farming soils affected by industry. Environment International, 30:159 -165.

Muller, G. 1969. Index of geo-accumulation in the sediments of the Rhine River. Geojournal, 2: 108-118.

Nwaogu, L.A., Ujowundu, C.O., Iheme, C.I., Ezejiofor, T.N. and Belonwu, D.C. 2014. Effect of sublethal concentration of heavy metal contamination on soil physicochemical properties, catalase and dehydrogenase activities. International Journal of Biochemistry Research \& Review, 4(2): 141-149.

Norman, M. D., Pearson, N. J., Sharma, A. and Griffin, W. L. 1996. Quantitative analysis of trace elements in geological materials by laser by ablation ICPMS: instrumental operating conditions and calibration values of NIST glasses. Geostandards Newsletter, 20: 247-261.

Norman, M.D. 1998. Melting and metasomatism in the continental lithosphere: laser ablation ICPMS analyses of minerals in spinel, herzolites from eastern Australia. Contributions to Mineralogy and Petrology, 130: 240-255.

Oladunjoye, M.A., Sanuade, O.A., and Olaojo, A..A. 2013. "Variability of Soil Thermal Properties of a seasonally cultivated Agricultural Teaching and Research Farm, University of Ibadan, South-western Nigeria," Global Journal of Science Frontier Research Agriculture and Veterinary, vol. 13, no. 8, 40-64

Rahaman, M.A. 1976. Review of the basement geology of southwestern Nigeria, In: Kogbe, C.A. (ed.) Geology of Nigeria. Elizabethan Publishing Company, Lagos, pp. 5-41.

Rahaman, M.A. 1988. Recent advances in the study of the basement complex of Nigeria. In: Geological Survey of Nigeria (ed) Precambrian Geol., Nigeria, pp. 11-43.

Shaapera, U., Nnamonu, L.A. and Eneji, I.S. 2013. Assessment of heavy metals in Rana esculenta organs from River Guma, Benue State Nigeria. American Journal of Analytical Chemistry, 4(9): 496-500.

Steffan, J.J., Brevik, E.C., Burgess, L.C. and Cerda, A. 2017. The effect of soil on human health: an overview. European Journal of Soil Science, 159-171.

Sultana, M.S., Rana, S., Yamazaki, S., Aono, T. and Yoshida, S. 2019. Health risk assessment for carcinogenic and non-carcinogenic heavy metal exposures from vegetables and fruits of Bangladesh. Cogent. Environ. Sci., 543-552.

Taylor, S.R. and Mclennan, S.M. 1985. The Continental Crust: Its Composition and Evolution. Blackwell, Oxford, pp.312.

Taylor, S.R. and Mclennan, S.M. 1995. The geochemical evolution of the continental crust. Reviews of Geooysics, 33(2): 241-265.

Tepanosyan, G., Maghakyan, N., Sahakyan, L. and Saghatelyan, A. 2017. Heavy metals pollution levels and children health risk assessment of Yerevan kindergartens soils. Ecotoxicol. Environ. Saf., 142: 257-265.

Tijani, M.N., Jinno, K. and Hiroshiro, Y. 2004. Environmental impact of heavy metal distribution in water and sediments of Ogunpa 
River, Ibadan area, southwestern Nigeria. J. Mining Geol., 40(1): 73-83.

USEPA 2012. Integrated Risk Information System of the US Environmental Protection Agency, Office of Emergency and Remedial Response: Washington, DC, USA,

Wei, B. and Yang L. 2010. A review of heavy metal contaminations in urban soils, urban road dusts and agricultural soils from China. Microchemical Journal, 94(2): 99-107.
Wongsasuluk, P., Chotpantarat, S., Siriwong, W. and Robson, M. 2014. Heavy metal contamination and human health risk assessment in drinking water from shallow groundwater wells in an agricultural area in Ubon Ratchathani province, Thailand. Environ. Geochem. Health, 36: 169-182.

Yongming, H., Peixuan, D., Junji, C., \& Posmentier, E. 2006. Multivariate analysis of heavy metal contamination in urban dusts of Xi' an, Central China. Science of the Total Environment, 355(1-3), 176-186. 